\title{
WOMAN'S CONFLICT FOR LIBERTY AND FINANCIAL INDEPENDENCE IN CHARLOTTE PERKINS GILMAN'S SELECTED POEMS
}

\author{
Asst. Instr. Adnan TaherRahma,Asst. Instr. Salman HayderJasim, Asst. Instr. Safaa Hussein Sagheer \\ Al-Imam Al-Khadhum College forIslamic Sciences
}

DOI: $10.37648 / \mathrm{ijrssh} . v 10 \mathrm{i} 02.016$

Received:07 $7^{\text {th }}$ January, 2020; Accepted:10 ${ }^{\text {th }}$ February, 2020; Published: 07th March, 2020

\begin{abstract}
Charlotte Perkins Gilman (1860-1935) is one of the greatest feminist writers, an advanced lecturer and a sociologist who provided philosophical leadership to the feminist movement of the late nineteenth and early twentieth centuries. Gilman's efforts deal mainly with the status of women. As a feminist she challenges the social hierarchy that makes woman distinctively and naturally inferior to male. Definitely, she protests forcefully against the idea of masculine sovereignty and high rang of social supremacy by blaming the patriarchy for abasement and preserving gendered instruments that make women second class citizens. Her interest in women arose from a concern that, as one-half of society and humanity, their restricted role in society retarded human progress. Thus, Gilman's contribution to feminism must be observed within the context of her humanist philosophy.
\end{abstract}

How women were confined to their homes, may have been primarily enticed by Gilman's poetry and her other literary works. She exemplifies the image of woman as a victim under the authority of patriarchal system specifically in the Victorian American period. This system deals hostilely with a female as a self-defeating, submissive, second citizen and obedient servant. Therefore, there is acrucial and essential change in woman's status to break the old belief which states that the appropriate place for woman should be at home to take care faithfully and tirelessly the members of her family. In her poetry, Gilman tries to highlight how woman can make a fundamental change in society by contributing in public life effectively. In other word, Gilman calls for liberation of women from the severe ties of domesticity through financialfreedom and independence.If they were allowed equal opportunities with men in truly human activities, society would be promoted not only from their direct works, but also the children would finally have two fully human parents with actual responsibilities.

Gilman also argued against the idea that women could not successfully combine a career and marriage. She says "Work doesn't make a woman less womanly.", on the contrary, economic freedom would free woman to become full member of society and to achieve balance with her. Turning from domestic service to social service, they would enter into organic social as functional parts of the social body.

Key words: Gilman, women, struggle, feminism, economic, independence 


\section{INTRODUCTION}

As the successor to earlier females who had meaningfullyaffectedsocial reforms in the United States of America, it is not astounding that Gilman was a fundamental and protuberant American feminist and became one of the authentic Americanwomen during the feminist movement of the late nineteenth and early twentieth-century. She was a perfect feminist and served as a model for future generation of feminists because of her unconventionalideas and lifestyle. When she was young, her father left home with depressed and helpless wife and a heavy duty of two children. The family wasforced to move nineteen times in eighteen years from one place to another because of the absence of financial secure (Kim Wells, 1999, p.1-2). Gilman educated at an early age to depend economically and ardently upon her great aunts, Beecher women. Gilman never impressed or enthused by the traditional local limits set forth for women of nineteenth century. Her fast increasing philosophy towards female freedom along with her own childhood experience with her father caused her to have uncertain senses about marriage (ibid).

Nevertheless; she married the brilliant artist Charles Walter Stetson (1858-1884) and soonthen had only child, Katherine. Gilman's negative participationsthroughout her first marriage supported her reproach towards the domestic prospects and suppression of middle and upper- class women. After breaking from marital manacles, Gilman sought to start a widespread forum to enhance her radical views about a woman's role in society. Her reform writings and involvement label her as a radical; yet, her social criticism reached far beyond the typical suffragist union member. To fully free women, the visionary Gilman thought that American society should be rebuilt in a collectiveway (Gary Scharnhorst, 1985, p. ii).

Gilman's sadness at trying to accomplish the traditional place as a late nineteenth-century, white woman in a middle-income marriage laidawideoccupationchiefly focused on gaining women's sovereignty. Her career development as a creative essay and narrative writer, as well as a political activist, attached with her frank writing style, and radical messages, signaled an outright refusal of accepted gender biases. Gilman related with a much more fundamental group and not astonishingly her eccentric lifestyle and notions brought criticism upon herworks. However, Gilman's persistent work and faith in women's equivalence persisted to the end of her life (ibid, 31).

Gilman showed that the vital concern for women is work and contributeefficiently in communal life. She was an avid advocate of women's suffrage and their societal interferences and restraints which prevented them from achieving economic independence and she powerfullyfortified women to follow interests outside the domestic scope. Her opinions on the place and future of women were sought, observed upon, and keenly discussed in the United States and Europe. The movement in Gilman's writing increasingly develops the potentials and highlights the key barriers for a woman: female confrontation to social change and male skepticism concerning the need for work in a woman's life. She envisaged the conversion from the present to the future as one of interior conversion to ademocratic society (Carl N. Degler, 1956 p.vi).

The concepts about traditional masculinerelations and its effects on women developed at an early age in Gilman's dream. She was the successor of numerous outspoken and reformer women of Beecher family (the old and enthusiastic Unitarian family) such as author and abolitionist Harriet Beecher Stowe (1811-1896) originator of the Hartford Female Seminary, Catharine Beecher (1800-1878) well-known for her support of women and education and suffragist Isabella Beecher Hooker (1822-1907) famous for her work as a cohort of other pioneers females in women's suffrage movement. Thus, Gilman had several female role- replicas that struggled for human and female equivalence through social liberation, educational and political chances. The absence of a male figure in most of Gilman's childhood and youth contributed to make a strong variation of a new role for financial independence as a part and parcel of her admiration towards women. Gilman's father left his family fatherless and poor and she learned early to question the holiness of the home, the domestic folklore and the role assigned to women within the marital family (ibid, 2).

Gilman engrossed herself in literature, rather than in dress and method codes for women. Her proper education was limited, but she read individually and insatiably. Ralph Emerson (1803-1882) captivated her as a radical poet, as did Walt Whitman (1819-1892) in her later years. The only female writers she looks to have read and familiar with though, were emotional fiction and nonfiction authors, such as Louisa May 
Alcott (1832-1888), Margret Fuller (1810-1850) and Emily Dickinson (1830-1886). Although her opinions about these women authors are unknown, her interest in them is important because they, like her ancestors, broke from the traditional female role by using their notions in social improvement and literature (Scharnhorst, 2).

Though very dissatisfied in her first marriage, Gilman made efforts to free herself of anguish. In order to keep her saneness, Gilman attempted to promote the academic and advancedrange. For example, she attended the first suffrage agreement in 1886 and began to write for resident papers and journals. In 1887, the despondent wife struggled to cure her misery by taking a "rest cure" (democraticvistas.net) under the supervision of nerve expert S. Weir Mitchell (18291914). Mitchell's cure limited everything that Gilman felt was positive. His conduct was "intended to decrease a female patient to the state of innocent docility" and she was instructed to diminishacademic activity to two hours a day and "not ever touch pen, brush, or pencil as long as possible she lived" (ibid, 3).

Emancipation from the manacles of her marriage, Gilman began to devote her time writing fiction and nonfiction to endorseliberation for all ladies. Following her separation, she moved to Pasadena, California where she focused firmly on her literature, which was "basically, an unrepentant defense of didacticism" (9). As a lone mother using her literary work as a mean of support and achievement to show that she was not a stereotype of nineteenth century restricted woman. Gilman's moral agenda and economicalwantencouraged her to write many poems, short stories and articles published in magazines that "compassionatelydepicted a strong and disobedient young woman who attacked the call to marry and how to be financially protected" (11). Gilman wrote such poems and stories to support and enhance female freedomand encourage women not to fall into the same depression that she had. They were not very much literally autobiographical as many critics thought; nonetheless, Gilman risked societal ostracism because she was a single mother in the late nineteenth century (11-12).

In addition to her writing, Gilman tried to help humankind through her work as a nationalist in the 1890's. Nationalism was synonymous with Collectivism in many respects and parts. Gilman was partially drawn to the movement because it professed to liberate women through economic as well as political combination: "Women will be independent monetarily, not of each other, not of the race, but of this revolting condition of dependence upon man with whom they hold the relation of marriage" (13).

Even though, Gilman was disliked as a businesswoman, society was able to admit her more willingly as a writer, which was a more accepted occupation for women at the time. Her first book, In This Our World, a collection of verse published in 1893, was well received by thinkers in the Eastern United States as well as England. All over this volume of poems, she produces poems that are bold in both style and substance. She also addresses the disgrace, subjugation and lowliness of women by patriarchal laws and how women can change their dilemmas of imprisonment and domestic confinement into a better life. Gilman's ability to comprehend and suggest remedies for women's role in late nineteenth-century America was depicted in her altered attitude towards oppression of women and marriage (26).

\section{WOMAN'S INDEPENDENCE AND FINANCIAL POWER}

During the mid-nineteenth century, the movement of woman advanced as a result of women's endeavors to improve their position in and utility to society. The purposes of the movement were to initiate procedures of benevolenttemperance, sympathy, and social wellbeing and to initiate struggles for civil rights, social freedoms, higher education, well-paidprofessions, and the vote. The setting of these goals resulted from women's rising awareness of the precariousness of their situation in the male-controlled society of the $1800 \mathrm{~s}$ (Nancy Cott, 1987, p.3).

At this time, women were the continual sufferers of social and financial discrimination. Upper- and middleclass women's choices were limited to marriage and motherhood. Both choices resulted in domestic dependence. Though they could find jobs as factory workers or shop girls, women were discouraged from being income earners by the conviction that women who earned wages were abnormal. In addition, low wages, the absence of upward flexibility, miserable and unhealthy working circumstances, all made marriage agood-lookingexistence strategy for working-class women. Women were obliged, for a variety of reasons, 
to be reliant on their husbands for financial support (Carroll Smith, 1985, p.13).

Progressingthrough the nineteenth century, the Woman Movement industrialized in reply to women's dependent condition. It supported a series of new descriptions for women like: Real Womanhood, Public Womanhood, and New Womanhood. In a fast changing world where men were charged with the mission of creating and growing an industrial civilization from a wilderness, a true woman was expected to serve as the worthy of religion and guardian of civilized society. Intellectual pursuits were strongly discouraged; instead, a true woman was expected "to accomplish herself the natural arts of child education, domestic pursuits, and spiritual comfort” (Frances B., 1989, p.68).

Progressively and by the passage of time, need forced many women to abandon True Womanhood in order to fill places left by men who had gone off to fight during the civil war. Women took on the parts of teachers, office workers, government workers, and store workers. Southern women took on the organization of massiveestates with hundreds of slaves. In addition, thousands of women contributed in the war efforts as volunteers and nurses, attending to the boys in the wards, helping as teachers of former slaves, visiting camps. Over 2500 women from the North and South worked as nurses during the war. However, the greatest wartime factor affecting women was the number of victims caused by the war. Eventually, over a million men were wounded or killed, more than in any other American war before or since. This human loss formed a generation of widows, bachelors, and wives with restricted husbands, and enlarged the pool of women in awful need of income, especially in the South where women outstripped men by tens of thousands (Nancy Woloch,1994, p.223).

Throughout the period of the late nineteenth and early twentieth centuries, American women enlarged their position outside the domestic domain. Whether working along with their male counterparts for reforms, improving their economic status and ability through education, or fighting for political fairness through the election, women were increasingly recognized as humans, rather than as child bearing, family managing supplies. Concurrently, female literary inventor Charlotte Perkins Gilman promoted this cause through her works (Hannah J., 42).
As a woman during the Progressive era sought to improve women's status by presenting them as humans with desires, goals and accomplishments equalsto men. Gilman worked directly for women's emancipation and thought any goal attainable. Far from being a quiet observer, Gilman dedicated her entire life to improving the quality of women's lives through political activism, writing and journal publications. She often expressed her attitude that the United States was seriously undermining itself by incapacitating half the population's abilities. Gilman shared with other feminists the primary goal of illustrating female liberation from male-dominated spheres (ibid).

In her bookWomen and Finances, Gilman insists that achieving world work would eliminate women's intense self-consciousness, the sensitiveness beyondall need, the demand for measureless personal attention and devotion. Gilman thought that men had the benefit over women because they had been permitted to recognize their exceptionalability and were able to receive a living by using that skill. In contrast, Gilman proposed that women were not allowed to develop their natural aptitudessince they were obliged to accept their traditional role in society even if they were missing in the ability to take on that role. She believed that women, like men, needed to find eloquent work in order to live aexpressive life; what she was less certain of was whether, once women abandoned domestic labor and followedsatisfyingvocations, their marriages would continue (Gilman, 1998, 66).

According to Gilman's opinion, "The duty of human life is progress; we are here, not merely to live, but to grow." (ibid, 2). Thus, woman's female functions in maintaining and reproducing the race were basic, but they were only a prelude to her larger purpose of human development. Gilman further asserted that woman possessed a greater potential for humanness than man because in her capacity for giving birth she had developed as a gender trait the essential requirement for being human: a propensity for nurturing life and fostering its growth (ibid).

Gilman hypothesized that the suppression of women created in primitive times when man began to appropriate the domestic work of the mother caring for her young. As human infancy became prolonged, maternal purposesextendedconsequently. To provide for dependent progeny, women developed primitive 
businesses such as planting, reaping, cooking, weaving, and decorating. Gilman's opinion about that saying:

Whereas the male savage was still a mere hunter and fighter, expressing the katabolic forces, the female savage,gathered together and saved nourishment for the child, she enfolded it in garments and built a housing for its head. It was through the determinedactivity of this wish, the mother's desire to serve the young, that she began the first of the arts and crafts by which we live (6).

The significant thing for Gilman was that women were in the social body, but were not part of it; and for this cause they founded a sub-human class. She clarified saying: "There are many persons, living in and on our humanity, who are not human. One cannot be human without working. To work, to perform specialized service for other people is the indispensable condition of humanness." (18).Individuals who did not work as Gilman defined work, were not only sub-human they were parasites. Restricted to unspecialized domestic service in the egoistic environment of the family, the female fit this doubly demeaning description (20). Gilman argued that mankind could never realize its human potential with half the race living in a dehumanized state. Thus, the "woman Problem" was in reality a human problem. Its solution rested upon a singular imperative: Women must become part of the social structure and its institutions. They must literally and metaphorically join the human race. This entailed offering beyond the female scope of domesticity into the world of human affairs, not an easy move in light of belief of the society that "Woman's place is in the home (Helen Jo Potts, 422).

Due to the important appearance of many tendencies in the second half of nineteenth century regarding woman's place in American society, Gilman's position was fundamental rather than radical because she did not promote an overthrow of the male-female relationship. She sought to enhance the relations between the sexes by replacing hierarchy with equality, by exchanging authority for autonomy. She argued that women who are economically tied to their husbands lose their sense of individuality, as they are not able to be economically stood on their own two feet. As anoutcome, the frameworks of patriarchy are properly reinforced which cause the further subjugation of women. (ibid, 422).

Economic liberation is the stimulus of freedom and the key for women who wish to break the cycle of maternity and loveless marriage, as many women marry out of economic need even basic existence. Gilman's focus upon male-female relations asthe source of the problem and her proposal to establish sexual equality through women's economic independence implied a fundamental change in society. (425).

Gilman strongly believes in women's rights and fights for them all her life by writing poems about women's situations and their circumstances during the disturbances of nineteenth century. Gilman's life and concepts reflect her oppression and suppression as a woman in anartificial world. Over her poems, she could speak about her sincere hurts, highest determinations and darkest doubts such as "To the Housewife", "In Duty Bound", and "Wedded Bliss". Her poems talk about her fundamentalphilosophies of kichenless-house, day-care center and hired house cleaner to liberate women from the heavy load of housework to spare more time for their professional life. Her central idea is that it is the women's financial dependence on men which resulted in their inferior status, therefore; she advocates financial independence of women through the equal right to access to the workplaces. (438).

In her poem, "In Duty Bound", Gilman frames her difficulty as a wife and a mother within the belief of imprisonment and the consequences of her first marriage. Though Gilman harbored grave suspicions about her flexibility to marriage, she marriedfrom the artist Charles Walter Stetson in May 1884.This poem was first written in 1881 and published in the Boston women's journal directly after Stetson's proposal and later on it appeared in the second edition of "In This Our World" in 1895. This poem spirituallyreveals the state of Gilman after she was obliged to do her local duties and promises as a wife but not a writer. The marriage becomes even more complex with the birth of her daughter, Katherine, in March 1885. Gilman wants a specialized life while her husband wants a straight and domestic one. Motherhood proved to be a barrier for Gilman's ambitions for it consumed a lot of her time. For that reason the poet suffered a severe case of post-partum depression (Scharnhorst and Knight, 2012, $\mathrm{xx})$.

In duty bound, a life hemmed in, 
Whichever way the spirit turns to look;

No chance of breaking out, except by sin,

Not even room to shirk-

Simply to live, and work.

("In Duty Bound", 27)

This poem has a clearimportance in the time of Gilman's unhappiness and her mother's illness Mary Wescott (1829-1893). In its preliminaryrepetition, the poem involved of two stanzas with the theme of captivity and lowliness. Gilman presents the other side of her sense of mission to accomplish in the world the feeling of ambition unrealized because it exists in the frame of a woman's body. She envisages a lone woman with a life "hemmed in," pressed by the circumstances of womanhood and poverty to bend to a lesser life. She uses as the central image a woman in "A house with roof so darkly low" that she "cannot stand erect without a blow." Gilman expressed blatantly in this poem the struggle between the rights of womanhood and dreams of a higher life (Helen Lefkowitz Horowitz, 2010, 29). "In Duty Bound" gives a desolate picture of female existence:

An obligation pre-imposed, unsought,

Yet binding with the force of natural law;

The pressure of antagonistic thought;

Aching within, each hour A sense of wasting power.

(“In Duty Bound", 27)

The lives of women, both communal and historical, have been conquered, and often dominated, under the burden of domestic responsibilities. Gilman could not accept the notion of women being inferior to men, so she subsequently gives women tremendously powerful and persuasive roles in her writings. Gilman's words above characterized a dilemma faced by many nineteenth century feminists who sensed the threat of marriage to their identity and personality. Women who valued intellectual independence and who sought a career often rebelled against the authoritarian structure of Victorian marriage which cast wives into submissive roles limited to thedomestic sphere. Her reexamination stemmed from a need to investigate what she should do, not what she needed to do. While believing in concept that marriage and motherhood did not prevent a vocation, she continued to have reservations that domestic obligations would threaten her hard-won autonomy (Gilman, 1935, 89).
The poet stresses that being a career-wife was not only conceivable but wanted, from two positions. First, women need the company of marriage, second the individualgratification of a job. An either-or choice was as unusual for a woman as it would be for a man. Definitely, said Gilman; "It should not be a question of either-or. She doesn't wish to give up home and family for a wider world any more than he does" (www.she write).For either sex the fulfillment of function should not require the denial of a normal personal life. On the other hand, the career-wife was a requiredlocation because love alone was not enough to gratify either spouse in a marriage. In her poem, "Wedded Bliss," Gilman specified that men knew this fact but women did not:

'O come and be my mate!' said the Eagle to the Hen, 'I love to soar, but then

I want my mate to rest

Forever in the nest!'

Said the Hen, 'I cannot fly,

I have no wish to try,

But I joy to see my mate careening through the sky!'

They wed, and cried, 'Ah, this is Love, my own!'

And the Hen sat, the Eagle soared, alone.

("Wedded Bliss", 86)

Gilman's"Wedded Bliss" is a mocking poem at marriage, which raises the philosophy that men belong to the civic spaces of the world, while women belong to the private spheres which means home. This poem was first appeared in "In This Our World", "The Woman" feminist poems part and also in "Suffrage Songs and Verse" in 1911 for its significance. In this poem, Gilman tries to employ a male and strong depiction of the males (the Eagle, the lion and the Salmon), whereas, the feminine versions of nature are characterized by (the hen, the sheep and the clam). Males arecapitalized to designate the dominance of masculine society while females to indicate the lowliness and obedience (ibid).

'O come and be my mate!' said the Lion to the Sheep; 'My love for you is deep!

I slay, a Lion should,

But you are mild and good!

Said the sheep, 'I do no ill-

Could not, had I the will-.

But I joy to see my mate pursue, devour and kill.'

They wed, and cried, 'Ah, this is Love, my own!'

And the Sheep browsed, the Lion prowled, alone.

("Wedded Bliss", 86) 
This poem significantly embodies the best example of Gilman's philosophy about marriage. The Eagle gets to do and what he loves which is to "soar". The Lion gets to do what is natural to all lions which are to "kill". The Salmon declares his awareness and wisdom. Therefore, men have freedom, strength and wisdom. Each male model in this poem chooses a "mate" who produces the reverse of his masculine strengths. The rising Eagle tells the hen that he loves her, but that she must "rest/forever in the nest", while he is doing what he loves, revealing in his freedom she has to stay home and she agrees with it. The hen claims that she "cannot fly/I have no wise to try". She is gratified to stay at home and lay her eggs as all compliant hens do. She originates her desire from watching him exploring the skies; the sense of freedom only belongs to him (ibid).

'O come and be my mate!' said the Salmon to the Clam; 'You are not wise, but I am.

I know sea and stream as well.

You know nothing but your shell.'

Said the Clam, 'I'm slow of motion,

But my love is all devotion,

And I joy to have my mate Traverse Lake and stream and ocean!'

They wed, and cried, 'Ah, this is Love, my own!'

And the Clam sucked, the Salmon swam, alone.

("Wedded Bliss", 87)

The dominant Lion, who kills since it is his nature to be a killer, chooses a sheep because she is opposite of him, she is "mild and innocent". And like the hen, she likes sitting on the hobbies watching as he murders his victim. The wise Salmon also chooses a companionappears to be foolish and lack of knowledge; he knows the depths of the ocean because he's been around while she is innocent, simple and inexperienced. She does not know anything more than her "shell", the shell in this poem is usually stands for incarceration of home and she allows to this claiming herself unaware and residual quite as a good clam should (ibid).

What is interesting in this poem is that the Eagle, the Lion and the Salmon describe their mates first because that is what they assume about their parts as feminine friends. They express themselves in the same behaviorsshy, coward, obedient, submissive and inexperienced. They do not justify or need liberty and sovereigntysince they are not fully qualified to be self- governing and free. They are not bodily strong enough to kill or fly. Their attitude is less than their masculine mates, not wise or knowledgeable. And this is why they should stay inside their homes. Comparing with their adored men, they have adventures, live life to the fullest, experience worlds beyond their own and enjoy (ibid).

Another important and essential interesting feature that Gilman points out these weddings or these bonds between these polar opposites are not blissful and fulfilling as the title indicates. How can they be indifferent when each member of each marriage is left alone without the mate they choose for themselves? Each of the three stanzas begins with "O come and be my mate", but end with the same word "alone." According to Gilman this marriage is loveless, fake, empty and not what each of them has bargained for. One of the ways she felt sure marriage would improve under these new circumstances was that husband and wife would meet as colleagues in all avenues of their tangled lives, fostering a deeper, stronger union between them (ibid).

The difference between the sexes was, of course, a method upon which Gilman absorbed and obtainable in much of her writings such as poems, short stories and novels, and uncountable essays. Her determined campaign for equal rights was often overshadowed by the reality of female subjugation, and the poem "Wedded Bliss" became another means of expressing her sardonic views on the issue of subordination in marriage. At other times, Gilman's writing offered a bit of comic tone from the intensity of her work 'as a social reformer (Denise D. Knight, 1993, 23).

Gilman's"To the Young Wife", is a poem that takes a lot about herlocal mythology and imprisonment. Each culture has its own ways to treat women who live in it. Those ways rely on many features such as religion, customs, time, atmosphere and the awareness of society members. Essentially, Gilman starts with the Victorian phase, in that time man had tyrannicalexpert; he is the sign of all severe men in everywhere, while woman is a figure of loaded and distressed. Men have power over women and had ill-treated them emotionallyand physically. Furthermore, they restricted women to domestic spaces and prohibited them from playing social roles. So, a group of middle-class women had fought for equal rights, and Gilman was one of those women who had experienced of this indirect 
suppression and was one of its victims. She wrote this poem, "To the Young Wife" to improve women's circumstances and declared that women must be permitted form masculinebeliefs. This poem has asarcastic and convincing tone. The poem has also a lot of oratorical questions which evoke women's spirits and call for varying of their minds for better life. (https://swopdoc.com). One of these questions is repeated many times within the poem "Are you content....?" as follow:

Are you content, you pretty three-years' wife?

Are you content and satisfied to live

On what your loving husband loves to give,

And given to him your life?

("To The Young Wife", 58)

Gilman desires to ask the beautiful women of that time if they are gratified and content to live a boring life what by ignoring their dreams and determinations. Actually, she directly wants to transfer the anguish of woman's spirit who stands for all womenthrough the image of this young wife. Women are at the kindness and pity of their spouses without taking any attentions of their spiritual and psychological sides of their spirits. They give them their youth, love and also life itself. In other words, she wishes to say that women are deserted and obedient to their domestic roles as wives and mothers; they cannot do anything without the agreement of their husbands. Then, she is ridiculing them saying: "your adoring husband" since if the woman's husband loves her, he will do what his adored wants as a result she would be hisobedient and compliant servant (ibid).

Are you content with work, - to toil alone?

To clean things dirty and to soil things clean;

To be a kitchen-maid, be called a queen, -

Queen of a cook-stove throne?

("To The Young Wife", 58)

Over and over again, Gilman repeats and asserts the role of this wife as a kitchen-maid who spends most of her hours in doing her duties. She uses some dynamic images to show how women are suppressed and belittled. Ironically, the speaker narrows the range of extensions of their kingdom and describes those housewives as the "queen of a cook-stove throne". This means that they only have a power over their "kitchens" because they are actually "kitchens-maids" not queens (ibid).
And are you quite convinced this is the way,

The only way a woman's duty lies -

Knowing all women so have shut their eyes?

Seeing the world to-day?

("To The Young Wife", 59)

Gilman after a long fight with this struggle to help a large number of women to understand their position in society, she understands that she is not fighting flesh and blood, but simply the public opinion, patriarchal ideologies and gendered resolutions. Her primary aim is to shed the light on social conditions of society as a whole by improving women's conditions. When conditions become more human and equitablefor the half of each population of society, society as a whole would definitely advantage (Jeanne O'Farrell Eddy, 2010, 12-14).

\section{CONCLUSION}

Generally speaking, the reader is going to conclude that women have historically been treated as unequal and often inferior to their male counterparts. In the nineteenth century and early twentieth centuries, American and European women were not only legally prevented from owning property or voting; they also were denied access to higher education or participate in public life.

Charlotte Perkins Gilman refused the old-style married life customary for middle and upper class women at the turn of the twentieth century. Her independent decisions to do so ultimately led to careers as feminist poet and sociologist promoting female autonomy throughout the United States. Though, Gilman lived through much of the oppression women were struggling against, she separated, gave up care of her child, had economicloads, publishing in a patriarchal society, received harmful medical advice and battled depression; these problems exposed her to a life that many women in their echelon never witnessed. In spite her personal hardships, Gilman was unwavering in followingfreedom and achieves equality for women. Skillfully, she was committed to her liberal position and worked consistently to develop ideas that would help women. She argued that humanity shared between men and women was more important than sexual differences, that women should be released from the confinement of home to make a greater human contribution. 
Through her poems, Gilman competentlyexploits very especial and unique writing techniques or hold identical personal beliefs. Her writings represent turn of the twentieth century and its challenges, American feminism because she demonstrates woman's entrapment in a male-dominated culture and her struggle to overcome it.

\section{REFERENCES}

Cogan B. Frances. Ail-American Girl: The Ideal of Real Womanhood in Mid-Nineteenth-Century America. Athens: U of Georgia P, 1989.

Cott, Nancy. "The Grounding of Modern Feminism". New Haven: Yale UP, 1987.

D. Knight, Denise ed. "With the first grass-blade: Whitman's Influence on the Poetry of Charlotte Perkins Gilman," Quarterly Review. 11Summer 1993.

Degler, Carl N. "Charlotte Perkins Gilman on the Theory and Practice of Feminism," American Quarterly 8, Spring, 1956.

Eddy, Jeanne O'Farrell. "Concoctions and Life-Long Connections: Women in the Kitchen", Ph.D. Dissertation. New York: Skidmore College, 2010.

Gilman, Charlotte Perkins. In This Our World. Oakland, California: McCombs \& Vaughn, 1893. London T. Fisher Unwind, 1895.

Gilman, Charlotte Perkins. The Living of Charlotte Perkins Gilman: An Autobiography. New York and London: D.Appleton-Century Co., 1935.

Gilman, Charlotte Perkins. "Social, Domestic and Human Life," Folder 165, CPG Collection; CPG, Women and Economics, ed. Carl N. Degler New York: Harper and Row, Harper Torch books, 1966.CPG, "Who Owns the Children?" 1, Folder 165, CPG Collection.

Gilman, Charlotte Perkins. Women and Economics: A Study of the Economic Relation Between Men and Women As a Factor in Social Evolution. 1898; repr., California, 1998.
Horowitz, Helen Lefkowitz. Wild Unrest: Charlotte Perkins Gilman and The Making of The Yellow Wallpaper. Oxford: Oxford University Press, 2010.

Knight, and Scharnhorst eds. In This Our World and Uncollected Poems. New York: Syracuse University Press, 2012.

M.A. Jo Potts, Helen. "Charlotte Perkins Gilman; A Humanist Approach to Feminism” Ph. D.

Marriage According to Charlotte Perkins Gilman-She Writes, https://www.she write/ Com /profiles/blogs/marriage according to charlotte_ perkins_gilman. Accessed March 1, 2020.

Rosenberg, Carroll Smith. Disorderly Conduct: Visions of Gender in Victorian. America New York: Oxford University Press, 1985.

Scharnhorst, Gary. Charlotte Perkins Gilman. Boston: Twayne Publishers, 1985.

Wells, Kim. "Charlotte Perkins Gilman." Domestic Goddess, 1999. Online.

Woloch, Nancy. Women and the American Experience. 2nd ed. New York: McGraw, 1994.

www.womenwriters.netldomesticgoddess.

Accessed February 2nd, 2020.

http://democraticvistas.net/index.php/charlotte Perkins Gilman.AaccessedFebruary 9, 2020.

https://swopdoc.com/poem-to-the-young--wife-byCharlotte-PerkinsGilman.html, Poem: To the young wife by Charlotte Perkins Gilman-EassysAufsatz.Accessed March 3, 2020. 